\title{
A FOGYASZTÓI TUDATOSSÁG AFFEKTÍV ÉS KONATÍV KOMPONENSEI
}

\section{AFFECTIVE AND CONATIVE COMPONENTS OF CONSUMER AWARENESS}

\author{
Szücs Róbert Sándor ${ }^{1}$ \\ Debreceni Egyetem, Gazdaságtudományi Kar, Marketing és Kereskedelem Intézet, \\ H - 5000 Szolnok, Tiszaligeti sétány 14 . \\ https://doi.org/10.47833/2020.1.ECO.002
}

\section{Kulcsszavak: \\ fogyasztóvédelem \\ fogyasztói tudatosság \\ marketing \\ attitűd}

\section{Keywords:}

consumer protection

consumer awareness

marketing

attitude

\section{Cikktörténet:}

Beérkezett 2019. október 20.

Átdolgozva 2019. november 12.

Elfogadva: 2019. november 25.

\begin{abstract}
Összefoglalás
A fogyasztók saját maguk védelme érdekében nem szeretik beismerni, hogy a marketing üzenetek nagy hatással bírnak fogyasztói magatartásukra. A vásárlók hajlamosak tudatos vásárlóként leírni magukat, olyasvalakiknek, akik tisztában vannak fogyasztói jogaikkal. Ez a fogyasztók énvédő mechanizmusa. A fogyasztói tudatosság affektív komponensének vizsgálatakor ( $n=918$ fö) azt tapasztaltam, hogy az affektív komponens meglehetősen erös. Ezt azonban a fogyasztók tényleges cselekedetei nem támasztják alá kutatásom alapján ( $n=850$ fö).

Abstract

In order to protect themselves, consumers don't like to admit that marketing messages have a great impact on their shopping behavior. Shoppers tend to describe themselves as conscious buyers, like someone that is aware of their consumer rights. This is the self defense mechanism of consumers. Examining the affective component of consumer awareness ( $n=918$ persons) I found that the the affective component is very strong. However, this is not supported by real behavior of consumers according to my research ( $n=850$ persons).
\end{abstract}

\section{Trendek és a tudatosság}

Meglehetősen gyakran olvashatjuk a „tudatos vásárló” kifejezést, illetve kívánatos magatartásként emlegetik a "tudatos vásárlást”. Nem egyszerü azonban megfogalmazni mit is jelentenek ezek a kifejezések. A tudatosság meghatározásakor alapműnek tekintem a Hofmeister és Törőcsik szerzőpáros által megfogalmazott fogyasztói magatartást leíró trendeket. A trendek közül kiválasztva azokat, melyek a tudatosság szempontjából fontosak, kiegészítésekkel, felvetésekkel az alábbiakban ismertetem őket [9]:

A fogyasztók egyre inkább öntudatosak, függetlenségre vágynak és nem kívánnak mintákat követni. Sajnálatos tény azonban, hogy még az internet korában sem képes a fogyasztó az adatokat tökéletesen feldolgozni és racionális fogyasztói magatartásban összesíteni, mint ahogyan ezt látni fogjuk.

\footnotetext{
${ }^{1}$ Kapcsolattartó szerző: E-mail: szucs.robert.sandor@econ.unideb.hu
} 
- Szokatlanul és nehezen felismerhető módon viselkednek, ellentmondásba keverednek saját magukkal, kiszámíthatatlanok. Ezek a jelzők semmiképpen sem a tudatosság irányába mutatnak.

Igénytelenek és igényesek is egyidejüleg, a képzettségi szint emelkedik; bizonyos termékekből a legjobb minőséget keresik, míg másokból a leggyengébb minőséggel is beérik. A jelenség nem feltétlenül jövedelemfüggő. A tapasztalatok alapján láthatjuk, hogy a képzettségi szint emelkedése nem jelenti feltétlenül a fogyasztók tudatossági, jogtudatossági szintjének emelkedését is egyben. Kutatómunkám ennek vizsgálatát helyezi középpontjába.

- Döntéseiket az érzelmek jelentősen befolyásolják, mely jelenség szintén nem a racionalitás és tudatos vásárlás legfőbb ismérve.

- A fogyasztó érzi, hogy nem helyes a fogyasztást választani pótcselekvésként a problémák megoldására, de ettől függetlenül mégis vásárol. Ennek gyökerei a gyermekekkel folytatott marketingaktivitásban is keresendők [18]. A jövő fogyasztóiért folytatott harcban a vállalatok igyekeznek a fogyasztói lojalitást már a idejekorán megszerezni, márkahüségre nevelni a gyermekeket. Kifejezetten nekik címeznek egyes reklámüzeneteket [10], [14]. Elméleti síkon a gazdaság viszonylag hamar megtalálta a gyermek helyét a fogyasztói társadalomban, beillesztette őket a David Fincher által megfogalmazott fogyasztói társadalmi filozófiába: „Akkor mik vagyunk mi? Nem tudom, hát... gondolom, fogyasztók. Úgy van! Mi fogyasztók vagyunk, az életszínvonal-megszállottság melléktermékei. Bünözés, éhezés, szegénység? Ezekkel nem törődünk. Mi izgat minket? A színes magazinok, a televízió, az 500 csatorna, egy név az alsógatyánkon, Viagra, hajnövesztő, műolaj" [7]. A gyermek- és fiatalkorúak szegmensében alkalmazott, rendkívül hatásos és hatékony marketing eszközök alkalmazásával, az egészen fiatal gyermekkorban kialakított márkahüséggel a vállalatok esélyt sem adnak a valódi tudatosság kialakulásának.

A fogyasztók diszkrecionális jövedelme emelkedik. A KSH 2018-ban elkészített, 2017-es évre vonatkozó életszínvonal tanulmánya az alábbiakat írja: „2017-ben a háztartások jövedelmi helyzete tovább javult. Az egy före jutó éves bruttó jövedelem 1 millió 644 ezer forint volt, 9,3\%-kal magasabb, mint az előző évben, a nettó jövedelem pedig 1 millió 300 ezer forintot tett ki, ami 8,4\%-kal haladta meg az előző évit. A reáljövedelem 5,9\%-kal nőtt 2016-hoz képest. 2017-ben minden jövedelmi csoportban nőtt a fogyasztás, az egy före jutó összes személyes célú kiadás 1 millió 106 ezer forintot tett ki, reálértéken 5,7\%-kal magasabb, mint az egy évvel korábbi. 2018-ban a magyar lakosság életkörülményei szubjektív megítélésében a korábbi évekhez képest számos esetben pozitív változás érződik. Az élettel való elégedettség átlagértéke az előző években többnyire állandónak mondható 6,1-röl 6,5-re, a háztartás anyagi helyzetével való elégedettség 5,2-röl 5,5-re, a lakókörnyezettel való elégedettség átlagértéke pedig 6,6-röl 7,1-re nőtt." [12]. Korábbi élelmiszerpazarlással összefüggő vizsgálatok kimutatták, hogy a jövedelemszint emelkedése a pazarlás szintjének emelkedését vonja maga után, ami röviden a tudatosság csökkenésének irányába mutat.

\section{A tudatos vásárló}

Hofmeister és Töröcsik az alábbi megfogalmazással élt: „A vevő kiszolgáltatott a piac eladó szereplőjének (...) A fogyasztó ezzel szemben nem kiszolgáltatott. Tudatában van hatalmának, elvárja, hogy pénzéért értéket kapjon, fogyasztótársaival szolidáris, kiszűri a piacról azokat a vállalkozókat, akik érdekei ellen tesznek, akár azzal, hogy becsapják az államot, akár hogy a fogyasztók kárára akarnak nyereséghez jutni." [9] Ebben az értelemben a tudatos vásárló mindenképpen fogyasztó, semmiképpen sem vevő. A Tudatos Vásárlók Egyesülete a következőképpen fogalmaz: „a klasszikus fogyasztóvédelem szerint tudatos vásárló az, aki nem hagyja, hogy átverjék. Aki tisztában van fogyasztói jogaival, és él is velük." [23] Dudás megítélése szerint a tudatosság nem homogén kategória, szintetizálja a különböző definíciókat. A tudatosság különböző aspektusaira hívja fel a figyelmet, úgymint egészségtudatosság, minőségtudatosság, ártudatosság, márkatudatosság, fogyasztói jogok tudata, céltudatosság, felelős fogyasztás, fenntartható fogyasztás, környezettudatos fogyasztás, társadalmilag felelős fogyasztás, etikus 
fogyasztói viselkedés, termék-eredet tudatosság, pénzügyi tudatosság, Kutatása szerint a vállalatoknak egyre nagyobb figyelmet kell szentelniük a tudatos fogyasztókra, mely számos feladatot ró a vállalatokra, úgymint:

ki kell elégíteni a minőséggel, illetve a kedvező ár-érték aránnyal kapcsolatos elvárásokat, számítani kell a fogyasztók növekvő önérdek-érvényesítésére, a fogyasztói jogok fokozódó ismeretére,

- a TVI-index eredményei szerint a magyar fogyasztók növekvő része próbálja meg tudatosan elkerülni a szokásos „marketingtrükköket”, ellenáll a reklámoknak, elöre tervez, céltudatosan vásárol, és ez alternatív marketingeszközök bevetését igényli,

az egészség jó hívó szónak tekinthető,

- növekvő a környezet- és társadalomtudatos fogyasztók tábora, érdemes a szokásos CSRtevékenységeken túl valódi folyamat- és termékfejlesztésbe fogni,

a fogyasztók hitelességet és őszinteséget várnak el a vállalatoktól stb. [6]

A fogyasztók erős énvédő mechanizmusuknak engedve meglehetősen tudatos fogyasztónak vélik magukat. Korábbi, 2011-ben lefolytatott, élelmiszerekkel kapcsolatos 1297 före kiterjedő kutatásom alapján megállapítást nyert, hogy az általában vett tudatosság mértéke 3,91-es értékkel írható le egy 5 fokozatú, növekvő skálán, míg a jogtudatosság mértéke 3,64-es értékkel bír [17]. Látszólag az értékek kedvezők. A vizsgálat azonban a tényleges tudásszint mérésére nem terjedt ki, így joggal nevezhetjük ezt a fajta tudatosságot a fogyasztók önbevallásán alapuló, vélelmezett tudatosságnak. Süle 280 egyetemi hallgatóra kiterjedő kutatásában vizsgálata azt, hogy a megkérdezett neme és fogyasztóvédelmi oktatásban való részvétele hogyan hat a fogyasztói tudatosságra. Kutatásában kiemeli, hogy a női fogyasztókat sokkal inkább jellemzi a hedonista fogyasztás és árérzékenység, mint a férfi vásárlókat. A Veblen-hatás erősebb a férfiak esetében, és nagyobb bizalmat támasztanak a jól ismert márkák irányába. A felmérés során kiderült, hogy mind a megkérdezett neme, mind pedig a fogyasztóvédelmi oktatásban való részvétel befolyásoló tényező, de sem a megkérdezett neme, sem pedig a képzettségi szint alapján nem lehet egyértelműen azonosítani a fogyasztói tudatosság szintjét. A vizsgálati eredmények azt mutatták, hogy a „,képzett” fogyasztók viselkedésének főbb jellemzője az árérzékenység, míg a többi („nem tanult") csoport tagjait sokkal inkább a marketing és a márkák befolyásolták. Kiemeli azonban, hogy az eredmények nem általánosíthatók országos vagy globális szinten, azok elsősorban a magyarországi egyetemistákra vetíthetők ki. [17]

\section{Problémafelvetés, kutatási cél}

Kívánatos magatartás a tudatos vásárlás, azonban számos tényező hátráltatja, nehezíti ennek megvalósítását. Általánosan elfogadott tény, hogy a vásárlások mintegy $80 \%$-a érzelmi alapú, csupán a fennmaradó $20 \%$ tekinthető racionális döntésnek. Nem elhanyagolható az impulzus vásárlások aránya sem. Hoyer et al. az impulzus vásárlások arányát $27-62 \%$ közé teszi, mely mérték termékfüggő [11]. Sumit szerint a ruházati termékek esetében ez az arány kb. 40\%, míg az teljes impulzusvásárlások 14\%-a élelmiszer [15]. Nem szabad ugyanakkor elmenni az egyén énvédő mechanizmusa mellett sem. 2011-es kutatásom során az alábbi érdekességre lettem figyelmes: A megkérdezett fiatalok pontosan látták azt, hogy mások gyakran vásárolnak felesleges dolgokat a reklámok hatására $(4,16)$, ellentétben a megkérdezett személyével, aki szinte sohasem $(1,73)$. A reklámok befolyásoló képessége kapcsán is megfigyelhető ez az ellentmondás a társadalom egészére $(3,67)$ és a megkérdezett személyére $(1,94)$ kifejtett befolyásoló hatás tükrében. Fenti adatok egy 5 fokozatú Likert-skála értékei voltak, ahol az 1-es érték a teljes elutasítást, míg az 5-ös érték a teljes egyetértést jelentette az adott állításokkal szemben. Feltűnő volt a fiatalok elutasítása a reklámok hatására történő felesleges dolgokat vásárlása és a reklámok hétköznapisága kapcsán. Továbbá megfigyelhető volt a fiatalok magabiztossága jogtudatosságuk $(3,64)$ és tudatos vásárlói mivoltuk $(3,91)$ kapcsán. Ha végig gondoljuk az adatok mögött rejlő jelenséget, akkor jelentős ellentmondásra lehetünk figyelmesek a válaszokban. Egyértelműen és jól látszik a válaszokból, hogy a tényleges ismereteken alapuló valós (fogyasztóvédelmi értelemben, tényleges tudással is alátámasztható) és a vélt (a fogyasztó saját magáról alkotott idealizált képe, véleménye, hite) tudatosság között hatalmas szakadék 
tátong. Ráadásul egy harmadik tényezö is kapcsolódik a fent említett két tényezőhöz, a valós- és vélt tudatossághoz, mégpedig az, ahogyan a fogyasztó a valóságban cselekszik. Tételezzük fel, hogy a fogyasztó ismeretei alapján a tudja, hogy egy tranzakció során a teljesítés nem megfelelő volt a szolgáltató részéről (pl. a frissen vásárolt joghurt romlott volt, a vásárlást igazoló blokkot megőrizte a fogyasztó), de ez koránt sem jelenti azt, hogy a fogyasztó vissza is viszi majd a terméket az üzletbe, él fogyasztói jogaival. Az érezelem és tudás koránt sem azonos a cselekvéssel, tettekkel. Ha a fogyasztó racionális lenne, akkor a három tényező között nem lenne lényegi eltérés, ellentmondás. Azonban, mint tudjuk, a fogyasztó nem racionális a marketing tudományágának értelmezése szerint, sokkal inkább egy emocionális, érzelmek által vezérelt lényröl szoktunk értekezni. Ha a fogyasztó igazán tudatos lenne, akkor minden marketingaktivitás ellenére lehetetlen lenne az, hogy az impulzusvásárlás, illetve az emocionális vásárlások ilyen jelentős mértéket ölthessenek. Látható, hogy hatalmas különbség van a vélelmezett tudatosság és a tényleges tudatosság szintje között. Emellett belátható, hogy nagyon komoly összefüggés áll fenn a valódi tudatosság és a tényleges tudás között; hiszen tényleges és pontos ismeretek nélkül senki sem lehet tudatos vásárló. Kijelentésemet igazolja Ishak Suraiya számos szerző munkásságát szintetizáló tanulmánya, mely rámutat arra, hogy a fogyasztó tudása jelentős hatást gyakorol a tudatos fogyasztói magatartás különböző típusaira [16], [13], [8], [5], [22], [2], [3], [4].

A valós és vélt tudatossághoz kapcsolódik a magatartási komponens. Értelmezésemben a tudatosság az élelmiszerek területén nem csupán azt jelenti példának okán, hogy a fogyasztó elolvassa az élelmiszereken található különböző jelöléseket, fogalmakat, hanem azt is, hogy érti azokat, tisztában van azok jelentéstartalmával, sőt, meg is tudja fogalmazni, mit jelentek ezek számára (valós tudás, valódi tudatosság), emellett a fogyasztó olyan terméket vásárol, mely ismeretei szerint szervezete számára valódi értéke hordoz. Nem elegendő az, hogy a fogyasztó tudja, hogy a rostokban, vitaminokban gazdag étrend kedvező szervezete számára, erröl információkat gyűjt, tájékozódik, ha a valóságban másként cselekszik, vagyis a magas zsír,- só,és cukortartalmú élelmiszereket lelkesen vásárolja ezek helyett. Összegezve, értelmezésemben a három tényező együttes összhangja szükséges a tudatosság megvalósulásához.

Kutatásomban elfogadom és alapként kezelem az általánosan elismert Allporti attitüd definíciót, mely szerint az attitűd tapasztalat révén szerveződött mentális és idegi készenléti állapot, amely irányító vagy dinamikus hatást gyakorol az egyén reakcióira mindazon tárgyak és helyzetek irányában, amelyekre az attitűd vonatkozik [1]. Értelmezésemben a tudatos fogyasztói magatartás mechanizmusa hasonlítható az attitüdhöz, aminek szintén 3 komponense van:

kognitív (ismereti) komponens. Példaként említve vizsgálhatjuk azt, hogy a társadalom tagjai ténylegesen és mérhető módon ismerik-e az élelmiszerekkel kapcsolatos fogalmakat, megnevezéseket.

affektív (érzelmi) komponens, ami a pozitív és negatív érzésekben ölt testet. Kutatási témakörömnél maradva vizsgálhatjuk azt, hogy a fogyasztók milyen mértékben tulajdonítanak saját maguknak tudatos fogyasztói magatartást.

konatív (magatartás-tendencia) komponenst, ami magát a cselekvést fejezi ki, például megvásárolja, előnyben részesíti-e a fogyasztó példának okán a rostokban gazdag élelmiszereket a magas zsír,- só,- cukortartalmú élelmiszerekkel szemben; vagy a fogyasztó vajon cselekszik-e, ha tudja, hogy jogsérelem érte egy tranzakció során.

Korábbi tanulmányaimban [19], [20], [21] a tudatosság kognitív komponensével foglalkoztam, így jelen tanulmányomban kiegészítve a fenti munkásságot, a tudatosság affektív és konatív komponenseit vizsgálom.

\section{Anyag és módszertan}

A tudatosság affektív komponensének vizsgálata érdekében kérdőíves kutatást folytattam le 918 fős fogyasztói minta bevonásával, amely felmérés 15 megyére terjedt ki. A mintában a legnagyobb arányban a Jász-Nagykun-Szolnok megyei kitöltők voltak (39,1\%), de Pest megye $(24,5 \%)$, Bács-Kiskun megye $(20,0 \%)$, Békés megye $(5,9 \%)$, Csongrád megye $(5,2 \%)$ lakosai is képviseltették magukat. A falusi kitöltők aránya $20,2 \%$, a városi kitöltőké $56,3 \%$, a megyeszékhelyen élök 17,6\%-ban, a fövárosiak 5,9\%-ban voltak jelen a mintában. A 
megkérdezettek 68,9\%-a átlagosnak ítélte családja anyagi helyzetét. A kérdőíveket olyan személyek töltötték ki, akik az adott háztartásban/családban jellegzetesen az élelmiszerek beszerzését végzik. A kitöltésre 2018. november 20. és 2018. december 10. között volt lehetőség. A mintában a 14-18 éves korosztálytól a 70 év fölöttiekkel bezárólag, minden korcsoportból voltak kitöltők. A minta átlagos életkora: 42,2 $\pm 14,0$ év. A mintában a nők aránya $64,9 \%$, a férfiak aránya $35,1 \%$. Az érettségivel rendelkezők aránya a legmagasabb a mintában $(46,2 \%)$, majd őket követi a felsőfokú végzettséggel rendelkezők aránya (29,6\%), szakmunkás végzettséggel a megkérdezettek 18,2\%-a, míg általános iskolai végzettséggel a megkérdezettek 6\%-a rendelkezett.

A tudatosság affektív komponense mellett kiemelten fontosa annak vizsgálata is, hogy a fogyasztók tipikusan hogyan jártak el különböző, problémás vásárlási szituációkban. Ez tulajdonképpen nem más, mint a tudatosság konatív komponensének vizsgálata. Ennek megválaszolása érdekében 850 fő bevonásával kérdőíves kutatás került lefolytatásra 2018. novemberében és decemberében, olyan személyek bevonásával, akik rendszeresen megjelennek valós vásárlói szituációkban. A mintában a férfiak aránya $40,2 \%$ volt, míg a nők aránya $59,8 \%$. A minta átlagos életkora: $41,5 \pm 13,8$ év volt. Az érettségivel rendelkezők aránya a mintában 45,2\%, míg a felsőfokú végzettségüek $28,2 \%$-ot tettek ki. Tipikus válasz volt az átlagosnak ítélt anyagi helyzet $(68,4 \%)$, de az átlagostól kedvezőbb szituáció sem volt ritka jelenség $(20,7 \%)$. A megkérdezettek 47,9\%-a rendelkezett valamilyen szintü gazdasági végzettséggel. A kutatás összesen 16 megyére terjedt ki, a városi lakók aránya 57\%, a megyeszékhelyen élők 17,3\%-ban, míg a fővárosban élők 5,2\%-ban képviseltették magukat. A kutatás kérdőívében a megkérdezettek elöre meghatározott válaszlehetőségek közül választhattak, illetve teret engedve a saját véleményalkotásnak is, a megkérdezettek saját véleményt is fogalmazhattak meg az elöre rögzített opciók mellett (többkimenetelü kombinatív kérdés).

Az adatok feldolgozása során statisztikai módszereket alkalmaztam (átlag, módusz, medián, szórás, Cramer-féle asszociációs vizsgálat, Kendall-féle egyetértési együttható, kereszttábla vizsgálatok, faktor,- K-means klaszterelemzés, diszkriminancia-analízis stb.).

\section{Eredmények a tudatosság affektív komponensének témakörében}

A tanulmány jelenlegi részében arra kerestem a választ, hogy a Tudatos Vásárlók Egyesülete által megfogalmazott „a tudatos vásárlás 12 pontjával” a fogyasztók mennyire értenek egyet, azok mennyire jellemzik saját fogyasztói magatartásukat. Az Egyesület által megfogalmazott pontokat a fogyasztók által is értelmezhető állításokká konvertáltam, mellyel a megkérdezettek egy 5 fokozatú Likert-skálán fejezhették ki egyetértésük szintjét. Az Egyesület által megfogalmazott pontokat kiegészítettem továbbá 2 kérdéssel, illetve 1 állítással is. Ezek az 1 . számú táblázat első két sorában, illetve utolsó sorában találhatók. Az első két pont a megkérdezett saját és háztartásuk vélelmezett tudatossági szintjét méri. Nevezett két kérdés a fogyasztók önvédelmi mechanizmusának mérése okán került be a vizsgálatba. Az 1. számú táblázat utolsó sorának álítása egy a hétköznapokban is elterjedt a mondásnak az okán került a listára, miszerint éhesen ne menjünk vásárolni, így csökkenthető az impulzusvásárlások aránya, föként az élelmiszerek esetén. Ennek következtében a Tudatos Vásárlók Egyesületének 12 pontos listáját egy továbbival bővítettem (12+1 pont). A részletes adatokat az 1. számú táblázat tartalmazza.

1. táblázat. A tudatos vásárlás kibővített pontjaival szembeni egyetértés nemek szerint ( $n=918$ fö)

\begin{tabular}{|l|c|c|c|}
\hline \multirow{2}{*}{} & \multicolumn{2}{|c|}{ Nem } & \multirow{2}{*}{ Fóátlag } \\
\cline { 2 - 3 } & Férfi & Nő & \\
\hline Tudatos fogyasztónak tartja Ön saját magát? & 3,89 & 3,90 & 3,90 \\
\hline Tudatos fogyasztónak tartja Ön saját háztartását? & 3,67 & 3,53 & 3,58 \\
\hline $\begin{array}{l}\text { 1.A vásárlásommal/pénzemmel szavazok. A vásárlásommal döntöm el, } \\
\text { hogy mely eladót támogatok, mely eladót nem támogatok. }\end{array}$ & 3,36 & 3,21 & 3,26 \\
\hline $\begin{array}{l}\text { 2.Végiggondolom, hogy mit vásárolok, mert ha ki kell dobni a felesleget, } \\
\text { az lesz a legdrágább. }\end{array}$ & 4,03 & 4,24 & \multirow{2}{*}{4,16} \\
\hline 3.Vásárlás elött összeírom egy cetlire, hogy mire van szükségem. & 3,12 & 3,96 & 3,66 \\
\hline
\end{tabular}




\begin{tabular}{|l|c|c|c|}
\hline 4.A bevásárlóközpontok helyett a helyi piacokat támogatom. & 2,80 & 3,08 & 2,98 \\
\hline $\begin{array}{l}\text { 5.Kerülöm a felesleges nylonzacskót, viszek magammal a vásárláshoz } \\
\text { szatyrot, tudatosan keresem a visszaváltható termékeket. }\end{array}$ & 3,37 & 3,79 & 3,64 \\
\hline $\begin{array}{l}\text { 6.Kerülöm a nem természetes alapanyagból, vegyszerek segítségével, } \\
\text { iparilag elöállított ételeket. }\end{array}$ & 3,56 & 3,72 & 3,66 \\
\hline 7.Elolvasom az élelmiszereken található címkéket. & 3,19 & 3,42 & 3,34 \\
\hline $\begin{array}{l}\text { 8.Figyelek arra, hogy olyan termékeket vásároljak, amit állatkísérletek } \\
\text { nélkül állítottak elö. }\end{array}$ & 2,63 & 2,92 & 2,82 \\
\hline $\begin{array}{l}\text { 9.Figyelek arra, hogy olyan terméket vásároljak, amit sokáig tudok } \\
\text { használni, tartós lesz. }\end{array}$ & 4,07 & 4,06 & 4,07 \\
\hline $\begin{array}{l}\text { 10.Keresem a friss, hazai idényzöldséget és -gyümölcsöt, kerülöm a } \\
\text { több tízezer kilométert utaztatott termékeket. }\end{array}$ & 3,72 & 3,88 & 3,82 \\
\hline $\begin{array}{l}\text { 11.Keresem a lakókörnyezetemben elöállított, helyi termékeket. } \\
\text { 12.Keresem a legjobb terméket. Utánajárok, hogy a terméket ki állította } \\
\text { elö, mit tartalmaz, mibe csomagolják. }\end{array}$ & 3,15 & 3,49 & $3,0,37$ \\
\hline 12+1.Éhesen sohasem indulok élelmiszert vásárolni. & 2,83 & 3,06 & 3,05 \\
\hline
\end{tabular}

Forrás: saját kutatás, 2019 Tudatos Vásárlók Egyesülete [23] alapján

Fenti 1. táblázat első két sorának eredményei a megkérdezetteknek saját tudatosságukba vetett hitét mutatja, mely lényegében, élve a korábbi megfogalmazással egyfajta vélelmezett tudatosságot ábrázol számunka. Ez tulajdonképpen nem más, mint a fogyasztói tudatosság affektív, érzelmi komponense. A megkérdezettek saját maguknak tulajdonított átlagos 3,90-os tudatossági értéke összességében jelentős, jó szintű tudatosságra enged következtetni. Az érték jól illeszkedik a korábbi kutatásaim [18] eredményeihez, miszerint a megkérdezettek saját magukat tudatos fogyasztóként jellemzik általánosságban. A fogyasztók saját magukat családjuk más tagjainál is tudatosabbnak gondolják $(3,90)$, a megkérdezett tudatossága meghaladja a családjának tulajdonított tudatosság szintjét $(3,58)$. A jelenség kiválóan rávilágít az egyén énvédő mechanizmusának működési mechanizmusára.

A nők és férfiak majdhogynem hajszálpontosan ugyan olyan szintű tudatossággal jellemezték saját fogyasztói magatartásukat. A férfiak 3,89-os értékkel, míg a nők 3,90-os értékkel jellemezték saját tudatosságuk szintjét. Az apróbb különbségektöl eltekintve a válaszok alapján látszik, hogy a nőkre sokkal inkább jellemző az, hogy „cetlivel” indulnak vásárolni (3. tudatossági pont), mint a férfiakra. A férfiak esetében ezzel az állítással szembeni egyetértés átlagos értéke 3,12 , míg a nők esetén 3,96 . A vásárlás segítő „cetli” használata és a megkérdezett neme közötti összegfüggést feltáró Cramer-mutató értéke 0,29. Az érték önmagában nem mutat erős kapcsolatot az ismérvek között, természetesen más tényezők is hatással bírnak. A nők saját bevallásuk szerint sokkal inkább kerülik a nylonzacskók használatát, magasabb arányban keresik a természetes alapanyagból készülő termékeket, kerülik az állatkísérletekkel előállított termékek használatát, magasabb arányban olvassák el a termékek összetételjegyzékét, keresik a lakókörnyezetükben előállított termékeket, preferálják a helyi piacokat. Ennek tükrében egy érdekes jelenségnek lehetünk szemtanúi: a férfiak annak ellenére, hogy saját maguknak is alacsonyabb értéket adtak az egyes tudatossági pontokban, mégis átlagosan ugyan olyan tudatossági szinttel jellemezték saját fogyasztói magatartásukat (kb. 3,9), mint a nők. Ez gyakorlatilag azt jelenti, hogy a férfiak felülértékelték saját tudatosságuk szintjét, összességében elnézőbbek saját magukkal szemben.

A korábbi vizsgálatok eredménye alapján körvonalazódni látszott egy trend, miszerint a megkérdezett neme mellett a megkérdezett jövedelme is képes befolyásoló hatást kifejteni a vélelmezett tudatosság mértékére. A kutatás alapján láthatóvá vált, hogy a jövedelem emelkedésével a vélelmezett tudatosság szintje csökken még a megkérdezettek saját bevallása szerint is. A jövedelem emelkedésével növekszik az impulzus és emocionális vásárlások aránya, a tudatosság irányába mutató pontokkal szembeni egyetértés átlagos értéke pedig csökken (pl. 2., 3., 9. tudatossági pont). A jelentősen átlag alatti jövedelemmel rendelkező megkérdezettek saját tudatosságuk szintjét magasabb értékkel $(4,10)$ jellemezték, mint a jelentősen átlag feletti jövedelemmel rendelkezők $(3,46)$. A különbség leginkább szembetűnő a vásárlás előtti tervezés tekintetében (2. tudatossági pont), ahol a jelentősen átlag alatti jövedelemmel rendelkezők által adott 4,48-as érték a jelentősen átlag feletti jövedelemmel rendelkezők szegmensében már 3,68- 
os értékre csökken. Az impulzusvásárlások arányát csökkentő és egyben bevásárlást segítő „cetli” alkalmazásának aránya is jelentősen csökken a jövedelem emelkedésével (3,78-os értékröl 2,79re). Az sem meglepő, hogy az alacsonyabb jövedelemmel rendelkező megkérdezettek nagyobb figyelmet szentelnek a termék tartósságának, 4,24-röl 3,61-ra csökken az érték a jövedelemszint emelkedésével.

A vizsgálatok eredményeképp megállapítható az is, hogy az életkor emelkedésével a fogyasztók magasabb szintű tudatosságot tulajdonítanak saját maguknak. A magasabb életkorral rendelkezők az egyes tudatossági pontokban együttesen átlagosan 0,5-el magasabb értékkel jellemezték saját fogyasztói magatartásuk tudatossági szintjét, mint a fiatalabb életkorral rendelkezők. A leginkább jelentős különbségek abban rejlenek életkor szerinti bontásban, hogy az idősebb életkorú megkérdezettek szívesebben keresik fel a helyi piacokat, keresik a lakóhelyük környezetében elöállított helyi termékeket, illetve kerülik azokat a termékeket, melyekröl feltételezik, hogy nem természetes alapanyagból készültek.

A megkérdezett lakóhelye szerinti felosztásból láthatóvá vált, hogy a fővárosban élőkre kevésbé igaz, hogy a bevásárlóközpontok helyett a helyi piacokat preferálnák, illetve átlag alatti mértékben igaz az is rájuk, hogy a lakókörnyezetben előállított, helyi terméket preferálnák.

A várakozások ellenére, az egyes pontokra adott válaszok átlagos értékekeit vizsgálva a megkérdezett iskolai végzettsége szerinti felosztásban egyértelmű és általánosítható trendek nem mutatkoztak. A válaszok alapján ezt két jelenség okozhatja.

a magasabb iskolai végzettséggel rendelkezők szépítik válaszaikat, tudván a társadalmilag elfogadott normákat, így ezeknek az elvárásoknak megfelelően pontozták saját fogyasztói magatartásukat. Ebböl adódóan egyértelmű trend nem rajzolódik ki.

- az iskolai végzettség emelkedésével a megkérdezettek egyre kedvezőbbnek ítélték családjuk jövedelmi helyzetét. Az emelkedő jövedelemszint hatására bekövetkező tudatossági fegyelem csökkenést kompenzálja a magasabb iskolai végzettségből adódó tudatossági szint emelkedés. Ebből következően egyértelmű trend nem rajzolódik ki. Jelen kutatás egyik feltevést sem tudja igazolni, avagy cáfolni, bármelyik eset előfordulhat. Ez a végeredmény szempontjából irreleváns, sokkal inkább csak érdekességként szolgál.

\section{Eredmények a tudatosság konatív komponensének témakörében}

A tudatosság affektív komponense alapján kijelenthetnénk, hogy a fogyasztók tudatossága megfelelő szintü, további vizsgálatokra nincs szükség. Ez a kijelentés, azonban mindenképpen téves, hiszen az attitüd esetén is láthattuk, hogy a termékkel/márkával szemben felmutatott pozitív érzelmek (affektív komponens) koránt sem azonosak azzal, hogy a fogyasztó meg is fogja vásárolni az adott terméket/márkát (konatív komponens). A hazai termékekkel szemben felmutatott attitüdök, az etnocentrikus fogyasztói magatartás vizsgálatakor láthattuk, hogy a fogyasztó a szavak szintjén rendkívüli módon kedveli a magyar termékeket, általánosságban elégedett azok minőségével (affektív komponens), azonban azt is tudjuk a magyar fogyasztó csak a kasszáig mutat fel erősen etnocentrikus fogyasztói magatartást, a kasszához érve lelelkesedése drasztikusan csökken, még kis mértékü árkülönbséget sem fogad el, a külföldröl származó terméket teszi kosarába (konatív komponens). Leírt jelenség tisztázása érdekében mindenképpen szükséges a tudatosság konatív komponenségnek vizsgálata is, melynek föbb eredményei az alábbiak:

1. Amennyiben a fogyasztók kedvenc pékségükben nem friss pékárut kaptak, annak ellenére, hogy az eladó biztosította őket a termék frissességröl, a megkérdezettek 15,9\%-a tudomást sem vesz az átverésröl, elfogadja azt. Véleményük szerint nem nagy összegröl van szó, hiszen csak pékáru. Elfogadják, hogy kissé átverték őket, de ez „belefér”. Magukban elégedetlenkedek kicsit, de nincs jövőbeli kihatása az esetnek. A fogyasztói jogok hangoztatása helyett inkább a pékséget védik, egyetértenek azzal, hogy ott helyben meg kellett volna vizsgálniuk a pékárut. A megkérdezettek $34,1 \%$-a nem tesz semmit sem és a legközelebbi vásárlás alkalmával sem teszi ezt szóvá a pékségben, azonban újbóli előfordulás esetén más pékséget fog keresni, legalábbis szóban. A megkérdezettek 25,6\%-a a legközelebbi vásárlás alkalmával szóváteszi az esetet a kiszolgáló személyzetnek, $2,4 \%$ az 
üzletvezetőnek, de ezen kívül más következménye nem lesz az ügynek. Az azonnal visszatérők és reklamálók aránya csupán 10,3\%.

2. Kettős árfeltüntetés esetén (egyértelműen az alacsonyabb ár illetné meg a fogyasztót) a fogyasztók 5,7\%-a egyáltalán nem jelzi a problémát, elfogadja a magasabb árat reklamáció nélkül. Szintén az üzlet védelme jelenik meg a fogyasztói jogok érvényesítésével szemben („Magamban elégedetlenkedek talán kicsit, de nincs jövőbeli kihatása az esetnek. Rajta volt az $1999 \mathrm{Ft}$ is, ha ennyi, akkor ennyi.") A fogyasztók 20,5\%-a jelzi a problémát a kasszásnak, de elfogadja a magasabb eladási árat is. $2,6 \%$ üzletvezetőt hívat, de szintén elfogadja a magasabb eladási árat. A megkérdezettek 61,7\%-a kéri az alacsonyabb eladási ár felszámítását. $A$ fogyasztók 1,4\%-a gondolja úgy, hogy beírna a vásárlók könyvébe az eset kapcsán.

3. Egy romlott termék esetén (joghurt) a fogyasztók 15,7\%-a teljes egészében beletörödik a történtekbe, következmények nélkül, nem jelzi a problémát semmilyen formában sem. Véleményük szerint az a néhány száz forint nem nagy összeg, előfordul az ilyesmi, nem éri meg foglalkozni vele. 19,3\% a legközelebbi vásárlás alkalmával megjegyzi a kasszásnak az esetet (csere és pénzvisszafizetési igény nélkül, csak tudjon róla), míg 4,5\% a boltvezetőnél teszi ugyan ezt. A megkérdezettek 13,0\%-a visszaviszi a legközelebbi vásárlás alkalmával a terméket az üzletbe és kéri a termék cseréjét vagy árának visszatérítését. A megkérdezettek 35\%-a úgy gondolja, hogy nem az 500 Ft-ról van szó, hanem az elvröl, így azonnal visszamegy az üzletbe és szól, nehogy más megbetegedjen a terméktöl. Emellett az $500 \mathrm{Ft}$-ot visszakéri vagy cserét kér. Véleménye szerint így kiáll magáért és más fogyasztókért is.

4. Amennyiben egy üzlet polcain lejárt szavatossági idejű terméket találnak a fogyasztók, akkor a megkérdezettek $37,1 \%$-a szerint ez nem az ő problémájuk, a terméket nem vásárolnák meg, de nem szólnának a bolti személyzetnek. 56,2\%-a szóvá teszi a problémát egy bolti eladónak vagy a kasszásnak, hogy legközelebb jobban figyeljenek, illetve valamilyen módon kezelni kellene a problémát.

5. Egy magas árfekvésű müszaki terméket megvásárlása után azt beüzemelve, annak azonnali, 1 órán belüli meghibásodása esetén a fogyasztók 1,3\%-a csak 3 munkanapon túl vinné vissza a terméket. Meglátásuk szerint az is elegendő, hogy majd mondani fogják, hogy 1 órán belül a vásárlás után már elromlott a termék. Mindezt teszik annak ellenére, hogy mindent az előírásoknak megfelelően csináltak a beüzemelés során és a jótállási jegy és a vásárlást igazoló blokk is természetesen meglett volna.

6. Amennyiben a fogyasztó egy kínai üzletben nem kapna blokkot a vásárlásról, úgy a fogyasztók 49,6\%-a semmit sem tenne, szerintük ez megszokott jelenség. Meglátásuk szerint ők kedvező áron vásároltak, a többi nem érdekli őket. $A$ fogyasztók $31 \%$-a jelezné ezt a hiányosságot és kérné a bizonylatot. A hatósági bejelentést tevők aránya csupán $2,2 \%$-ot tesz ki.

7. Egy frissen vásárolt, ámde gyorsan tönkre menő lábbeli esetén a megkérdezetteknek 49,5\%-a próbálkozna a vásárlást igazoló blokk hiányában visszavinni a terméket az üzletbe. $32,5 \%$ a blokk hiányában meg sem próbálkozna a probléma jelzésével. Meglátásuk szerint felesleges visszavinni a terméket, „ez van, legközelebb figyelmesebbnek kell majd lenni”. 11\% szerint a vásárlást igazoló blokk nem szükséges a csereigény érvényesítéséhez.

8. Egy külföldi Aliexpress-röl vagy eBay-röl történő rendelés esetén, amennyiben a kifizetett termék nem érkezik meg, akkor a megkérdezettek 14,9\%-a nem tesz semmit sem, egyszerüen és csalódottan tudomásul veszi azt. Számukra a passzív beletörődés jut, meglátásuk szerint nem kellett volna ilyen messziröl terméket rendelni. Az eladónál reklamálók aránya $38,2 \%$, míg a hivatalos vitát (open dispute) kezdeményezők aránya 21,7\%.

9. Egy vásárlás során, amikor az áruk ellenértékét a megkérdezett készpénzzel egyenlíti ki, a kasszás a visszajáró összeget elszámolja. Feltételezésünkben egy $200 \mathrm{Ft}$-os érme helyett csak egy $100 \mathrm{Ft}$-os érmét ad vissza a kasszás a fogyasztónak. A megkérdezett a hibát még a kasszánál, azonnal észleli, a kérdés az, hogy hogyan jár el a megkérdezett. A megkérdezettek 14,5\%-a nem szólna a hiba kapcsán, hiszen csak 100 Ft-ról van szó, hiszen „az semmi, megítélésük szerint meglehetősen kellemetlen lenne szólni”. A megkérdezettek 84,2\%-a szól, a $100 \mathrm{Ft}$ az $100 \mathrm{Ft}$. Visszajár, legközelebb legyen figyelmesebb a kasszás, nem a megkérdezett hibázott. 


\section{Következtetések, javaslatok}

Abban a világban, ahol az eszközök jelentős része okos, a fogyasztók többsége sem engedheti meg magának, hogy ne tartsa saját magát tudatos fogyasztónak. Ameddig csupán a szavak szintjén kell bizonygatnia a fogyasztónak tudatos vásárlói mivoltát, addig ez különösebb nehézséget nem okoz számára. A fogyasztó erős énvédő mechanizmusának következtében nem akar vagy nem szeret tudomást venni saját felelősségéről és arról, hogy a marketing ingerek jelentős hatást gyakorolnak fogyasztói magatartására. Erős énvédő mechanizmusának következtében a fogyasztó gyakorta önmagával is ellentmondásba került. Saját magát tudatos vásárlónak írja le, egy olyan személynek, aki tisztában van a fogyasztói jogaival, aki a marketing ingerek hatására irracionális vásárlásokat jellemzően nem valósít meg. Ez a személy a fogyasztónak egy idealizált képe önmagáról, a saját fogyasztói magatartásáról elképzelt víziója. Ez egyfajta vélelmezett tudatosság, ami a fogyasztó fejében létezik csupán, de a való világban ez nincs így. A fogyasztók többsége hangoztatja tudatosságát. A hangzatos szavak azonban egy luftballonhoz hasonló módon foszlanak szét, amikor a fogyasztók fogyasztóvédelmi értelemben vett tudatosságát (a valódi tudatosságot) és a tudatosság affektív komponensét vizsgáljuk. Korábbi és jelen kutatás eredményeim is felhívják a figyelmet arra a tényre, hogy a fogyasztók annak ellenére tulajdonítanak saját magunknak tudatos fogyasztói magatartást, hogy azt a valóságban kognitív tudással vagy magatartással alá tudnák támasztani. Jelen kutatás eredményei jól illeszkednek a korábbi kutatások eredményeihez. Annak ellenére, hogy a fogyasztók jelentős része tudatosnak gondolja saját fogyasztói magatartását, csupán a fogyasztók 10-20\%-a sorolható - a bevezető részben bemutatott definícióknak is eleget tevően - a tudatos vásárlók csoportjába.

Fenti okfejtés, a valós és vélelmezett tudatosság közötti eltérés vizsgálata különösen érdekes lehet egy olyan szegmentum esetén, ahol a tudatosságra való törekvés (valószínüsíthetően a fent nevezett 10-20\%) megjelenik a fogyasztók gondolatkörében. Példának okán egy olyan szegmentumban, amely tesz az egészségének megőrzése érdekében, rendszeres sporttevékenységet végez; nagy kérdés, hogy esetükben hogyan alakul a valós és vélelmezett tudatosság közötti eltérés, hogyan befolyásolja az attitüdöket, a fogyasztást a fogyasztó saját magáról alkotott szubjektív testképe, a társadalom értékítélet. Jövőbeli kutatások tárgyát képezi, hogy a rendszeres sporttevékenységet végzők, azaz legalább heti egy alkalommal önszántukból sportolók milyen szintű tudatosságot képesek felmutatni, esetükben hogyan alakulnak az egyes komponensek az étrend-kiegészítők termékcsoportja kapcsán. A vizsgálat különösen érdekes lehet, mivel a termékkör szabályozása meglehetősen liberális.

\section{Köszönetnyilvánítás}

A publikáció elkészítését az EFOP-3.6.1-16-2016-00022 számú, Debrecen Venture Catapult Program című projekt támogatta. A projekt az Európai Unió támogatásával, az Európai Szociális Alap társfinanszírozásával valósult meg

\section{Felhasznált irodalom:}

[1] Allport G. W. (1955) Becoming: Basic Considerations for a Psychology of Personality, New Haven, London: Yale University Press, p. 115.

[2] Chartrand, T. L. (2005). The role of conscious awareness in consumer behavior. Journal of Consumer Psychology, 15(3), 203-210. http://dx.doi.org/10.1207/s15327663jcp1503_4

[3] Coulter, R. A., Price, L. L., Feick, L., \& Micu, C. (2005). The evolution of consumer knowledge and sources of information: Hungary in transition. Journal of the Academy of Marketing Science, 33(4), p. 604-619, http://dx.doi.org/10.1177/0092070305278512

[4] Dommeyer, C. J., Gross, B. L. (2009). What consumers know and what they do: an investigation of consumer knowledge, awareness, and use of privacy protection strategies. Journal of Interactive Marketing, 17(2), p. 34-51. http://dx.doi.org/10.1002/dir.10053

[5] Donoghue, S., De Klerk, M. (2009). The right to be heard and to be understood: a conceptual framework for consumer protection in emerging economies. International Journal of Consumer Studies, 33(4), p. 456-467.

[6] Dudás Katalin (2011): A tudatos fogyasztói magatartás dimenziói, Vezetéstudomány, XLII. ÉVF. 2011. 7-8. SZÁM / ISSN 0133-0179, p. $47-55$

[7] FINCHER D. (1999): Fight Club, 1999, Movie, Fox 2000 Pictures, min. 139 
[8] Hartlieb, S., Jones, B. (2009). Humanising business through ethical labeling: progress and paradoxes in the UK. Journal of Business Ethics, 88, p. 583-600

[9] HOFMEISTER-TÓTH Á. - TÖRŐCSIK M. (1996): Fogyasztói magatartás, Nemzeti Tankönyvkiadó Rt., Budapest, p.13.

[10] Hofmeister-Tóth Á. (2006): Fogyasztói Magatartás, Aula Kiadó, Budapest, p. 138-147.

[11] Hoyer W.D., Macinnis D.J., Pieters R. (2013): Consumer behavior, South-Western Cengage Learning, p. 259. (2018):
A háztartások életszínvonala

https://www.ksh.hu/docs/hun/xttp/idoszaki/hazteletszinv/hazteletszinv17.pdf, Letöltve: 2019.október 2., p. 33

[13] McEachern, M., Warnaby, G. (2008). Exploring the relationship between consumer knowledge and purchase behavior of value-based labels. International Journal of Consumer Studies, 32, p. 414-426, http://dx.doi.org/10.1111/j.1470-6431.2008.00712.x

[14] Sulyokné Guba J. (2000): Kis emberek, nagy piac, avagy a gyermek fogyasztóvá válása. In Marketing \& Menedzsment 34. évf. 2000. 2. szám p. 39-44

[15] Sumit R. (2013): Impulse shopping statistics, http://www.infographicsinsights.com/2011/04/impulse-shoppingstatistics.html, Letöltve: 2019. október 2.

[16] Suraiya Ishak, Nur Fariadah M. Zabil (2012): Impact of consumer awareness and knowledge to consumer effective behavior, October 2012, Asian Social Science 8(13), DOI: 10.5539/ass.v8n13p108, p. 108 - 114.

[17] Süle M. (2012): Can conscious consumption be learned? The role of Hungarian consumer protection education in becoming conscious consumers., International Journal of Consumer Studies. Mar2012, Vol. 36 Issue 2, p. 211-220

[18] Szücs R. S. (2011): A fiatalkorúak által fogyasztott néhány élelmiszeripari termék marketing és fogyasztóvédelmi szempontú vizsgálata, Debreceni Egyetem, Ihrig Károly Gazdálkodás- és Szervezéstudományok Doktori Iskola, http://hdl.handle.net/2437/103324

[19] Szűcs R. S. (2018): Jótállás a fogyasztók fejében, Economica, Vol. 9., No. 2., ISSN 2560-2322, p. 39 - 48.

[20] Szücs R. S. (2018): Kockázat és biztonság az online piactereken: A vásárlók tudatossága és a fogyasztóvédelem összefüggései, Economica, Vol. 9., No. 2. , ISSN 2560-2322, p. 31 - 38

[21] Szücs R. S. (2019): Az élelmiszerpazarlás és a fogyasztói tudatosság kapcsolata, Táplálkozásmarketing, ISSN 2064-8839, 6. évfolyam, 2019/1. szám, p. $69-80$

[22] Thomas, Jr. L., Mills, J. E. (2006). Consumer knowledge and expectations of restaurants menus and their governing legislation, a qualitative assessment. Journal of Foodservice, 17, p. 6-22, http://dx.doi.org/10.1111/j.1745-4506.2006.00015.x

[23] Tudatos Vásárlók Egyesülete: Mit jelent a tudatos vásárlás, http://tudatosvasarlo.hu/tve/gyik, Letöltve: 2019. október 2. 